\title{
"Integrated evaluation of investment attractiveness in the context of economic sectors: Ukraine as a case study"
}

\begin{tabular}{|c|c|}
\hline \multirow{6}{*}{ AUTHORS } & lurii Umantsiv (iD) \\
\hline & $\mathbf{R}$ \\
\hline & Ivan Cherlenjak (iD) \\
\hline & Volodymyr Prikhodko (D) \\
\hline & Yuliia Sonko (iD) \\
\hline & $\begin{array}{l}\text { ResearcherID: https://publons.com/researcher/1469157/yuliya-sonko/ } \\
\text { Maryna Shtan (iD) }\end{array}$ \\
\hline ARTICLE INFO & $\begin{array}{l}\text { lurii Umantsiv, Ivan Cherlenjak, Volodymyr Prikhodko, Yuliia Sonko and Maryna } \\
\text { Shtan (2021). Integrated evaluation of investment attractiveness in the context of } \\
\text { economic sectors: Ukraine as a case study. Investment Management and } \\
\text { Financial Innovations, 18(2), 118-129. doi:10.21511/imfi.18(2).2021.10 }\end{array}$ \\
\hline DOI & http://dx.doi.org/10.21511/imfi.18(2).2021.10 \\
\hline RELEASED ON & Monday, 17 May 2021 \\
\hline RECEIVED ON & Friday, 26 March 2021 \\
\hline \multirow[t]{2}{*}{ ACCEPTED ON } & Thursday, 13 May 2021 \\
\hline & $((c)$ EY \\
\hline LICENSE & $\begin{array}{l}\text { This work is licensed under a Creative Commons Attribution } 4.0 \text { International } \\
\text { License }\end{array}$ \\
\hline JOURNAL & "Investment Management and Financial Innovations" \\
\hline ISSN PRINT & $1810-4967$ \\
\hline ISSN ONLINE & $1812-9358$ \\
\hline PUBLISHER & LLC "Consulting Publishing Company "Business Perspectives" \\
\hline FOUNDER & LLC "Consulting Publishing Company "Business Perspectives" \\
\hline
\end{tabular}

NUMBER OF REFERENCES

26
NUMBER OF FIGURES

1

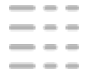

NUMBER OF TABLES

3

(C) The author(s) 2021. This publication is an open access article. 


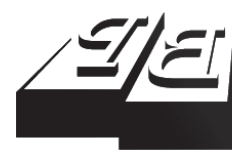

\section{BUSINESS PERSPECTIVES}

LLC "CPC "Business Perspectives" Hryhorii Skovoroda lane, 10, Sumy, 40022, Ukraine www.businessperspectives.org

Received on: $26^{\text {th }}$ of March, 2021 Accepted on: $13^{\text {th }}$ of May, 2021 Published on: $17^{\text {th }}$ of May, 2021

( ) Iurii Umantsiv, Ivan Cherlenjak, Volodymyr Prikhodko, Yuliia Sonko, Maryna Shtan, 2021

Iurii Umantsiv, Doctor of Economics, Professor, Department of Economic Theory and Competition Policy, Kyiv National University of Trade and Economics, Ukraine.

Ivan Cherlenjak, Doctor of Public Administration, Professor, Department of Business-administration, Marketing and Management, Uzhhorod National University, Ukraine.

Volodymyr Prikhodko, Doctor of Economics, Professor, Department of Business-administration, Marketing and Management, Uzhhorod National University, Ukraine.

Yuliia Sonko, Ph.D. in Economics, Associate Professor, Department of Public Management and Administration, Kyiv National University of Trade and Economics, Ukraine. (Corresponding author)

Maryna Shtan, Ph.D. in Economics, Associate Professor, Department of International Economic Relations, National Academy of Management, Ukraine.

This is an Open Access article, distributed under the terms of the Creative Commons Attribution 4.0 International license, which permits unrestricted re-use, distribution, and reproduction in any medium, provided the original work is properly cited.

Conflict of interest statement: Author(s) reported no conflict of interest

Iurii Umantsiv (Ukraine), Ivan Cherlenjak (Ukraine), Volodymyr Prikhodko (Ukraine), Yuliia Sonko (Ukraine), Maryna Shtan (Ukraine)

\title{
INTEGRATED EVALUATION
} OF INVESTMENT ATTRACTIVENESS IN THE CONTEXT OF ECONOMIC SECTORS: UKRAINE AS A CASE STUDY

\begin{abstract}
This study explores the evaluation of investment attractiveness of Ukraine's economy. The following factors are analyzed: the social significance of the sector, the coefficient of support for the sectoral development, the coefficient of production efficiency, the index of fierce competition, and the inflation index. The results of applying the calculation of the average value of the weighting factor within a particular sector and the method of the sum of sets show that the most significant influence on the investment attractiveness of the economy sector are factors of economic efficiency and support of the sector by the state. The study is based on the development and calculation of an integrated indicator of sectoral attractiveness. This approach makes it possible to take into account a set of factors and more accurately describe the existing priorities of a particular sector of the economy. The conclusion is that that the most attractive sectors in Ukraine are industry, trade, transport and communications, as well as financial activities. The education sector remains the least attractive for investment. It is estimated that its attractiveness does not exceed $10 \%$ of the threshold. Unattractive for investments sectors will need special attention from the government. Correcting the current situation and attracting additional investment in such areas can significantly reduce the burden on the state budget. The findings of this investigation can be used in order to expand the existing tools for the formation of economic policy of Ukraine and improve the practice of evaluation of sectoral investment.
\end{abstract}

Keywords

JEL Classification

\section{INTRODUCTION}

Ensuring investment attractiveness is a priority for the national economy. Investment is a catalyst for the restructuring of the economy and the solution of socio-economic problems. Activation of investment activity, formation of investment resources is the basis for economic growth. Investments are a fundamental source of sectoral development; they are inextricably linked with innovation processes and are one of the key elements of sustainable economic growth (Sonko et al., 2018). In the economy of Ukraine, there is a lack of sectoral investment, uneven distribution and reduction of public funding for investment processes. An important catalyst for the development of the sector is capital investment. It is primarily aimed at the reproduction of fixed assets, expansion, reconstruction and modernization of enterprises. Thus (according to the State Statistics Service of Ukraine) in the first half of 2020, capital investment in Ukraine decreased by $34.9 \%$. The volume of foreign investment currently does not meet the needs of Ukraine's economy. In 2020, the highest outflow of investment was in Ukrainian industry - almost $\$ 1.6$ billion. In the first 
quarter of 2020, investments from Cyprus decreased by $\$ 1.4$ billion, from Germany - by $\$ 427.5$ million, from the Netherlands - by $\$ 178.4$ million. The above shows that in today's conditions, the issue of increasing investment attractiveness is acute for the national economy.

Investment attractiveness as a set of subjective and objective factors that contribute to the investment process is primarily determined by a favorable investment climate. An important task of the government is to increase investment attractiveness by ensuring a favorable investment climate within the country. This can be achieved through the development and implementation of effective investment policies that minimize risks to investors, tax benefits, customs incentives, the creation of plans and programs, application of state contracts, development of public-private partnership, etc. The investment climate is formed under the influence of political, economic, financial and institutional conditions. The investment climate determines the incentives and opportunities for efficient production and expansion. Today, the export of agricultural products, industrial development and trade promotion are promising for the Ukrainian economy. Each sector has its own characteristics.

Every investor is faced with the question of choosing sectors that are promising for effective investment activities. At the same time, the government is also faced with a significant choice in identifying sectors that need support. The solution to these problems is based on the assessment of investment attractiveness in the context of economic sectors. The key task in the process of studying investment attractiveness is to conduct a qualitative factor analysis and identify the most important factors. The analysis of the factors that determine the conditions of development of a particular sector will identify obstacles and prospects for future investment activities. That is why the study of integrated evaluation of attractiveness in the context of the sectoral distribution is especially relevant in today's environment.

\section{LITERATURE REVIEW}

The scientific world pays considerable attention to the study of the concept of investment attractiveness. Problems of investment attractiveness have repeatedly been the subject of research by leading scientists. Investment attractiveness is often understood as an ability to encourage investment through offering combinations of location benefits possible to achieve within business activities. Areas offering an optimal combination of location factors create the best conditions for enterprises to function, and in consequence they attract investors (Borowicz, Kostyra, Dzierżanowski, Szultka \& Wandałowski, 2016). The role of state and regional policy in increasing sectoral investment attractiveness is often the subject of research by foreign authors (Globerman \& Shapiro, 1999). At the same time, studies (Jantoń-Drozdowska \& Majewska, 2016) note the similarity between the components of competitiveness and investment attractiveness as two additional categories and point to the role of new local advantages in determining the level of investment attractiveness.
Less often, the objects of research of the authors are the analysis of the spatial and sectoral distribution of foreign direct investment (Ramachandran et al., 2020) or the sectoral aspect of investment activities (Irtyshcheva et al. 2014; Maliuta, 2019; Reverchuk et al., 2020). Among the scholars who have studied this issue, it is also appropriate to single out I. Blank (Blank, 2001), who analyzed the prospects of the sectoral economy and proposed an integrated indicator of investment attractiveness, calculated using the ranking of indicators and the calculation of weights. Integral assessment is a widely used and effective tool for analyzing economic processes and phenomena (Naumenko et al., 2016; Yehorov, 2012; Riabovolyk, 2017). This will also be addressed during the research process.

Scientists often pay attention to the phenomenon of investment attractiveness and its assessment, investment opportunities and potential of regions or national economy (Kharlamova, 2014; Krykhivs'ka \& Chernyshova, 2017; Gutkevych, 2019). At the same time, researchers (Nosova, 
2003) often consider an approach that identifies the strengths and weaknesses of the object of investment, which in the future will allow the investor to determine the feasibility of potential investment in a particular economy sector. Other scientists suggest a list of key factors determine the level of investment attractiveness of economic sectors and rational methods of calculating the amount of funds invested in the development of economic sectors (Yemelianov et al., 2003). (Yemelianov et al., 2003) continued to study investment attractiveness on the basis of factor analysis and applied an approach based on a set of indicators grouped by common features to assess it. Hajduts'kyj (2004) emphasizes that all current methodological approaches do not provide an integrated assessment of the aggregate content of investment attractiveness. According to the author, a comprehensive approach to assessing the investment attractiveness of the economy as a multilevel system: at the national, sectoral, regional, business and project levels deserves attention. Ovcharenko and Stepanova (2017) point to the lack of a single universal method of assessing the investment attractiveness of the economy sector and the problem of completely different categorical understanding, which leads to significant differences in the choice of investment attractiveness. But most of the works of scientists focus on studying the problem of increasing the inflow of investment at the level of a particular enterprise, less often - the region Gliznutsa, 2016; Hryhoruk \& Khrushch, 2016; Sydor \& Davydovska, 2015; Dovhan, 2015.

An important place is occupied by research on the factors of investment attractiveness. Modern researchers (Ovcharenko \& Stepanova, 2017) provide such indicators as: net profit ratio, profitability ratio, cost-effectiveness, production efficiency, capital efficiency, return on investment, social significance of the sector, the share of employees in the total number of employees in the total in economics, etc. According to scientists (Ovcharenko \& Stepanova, 2017), "the creation of a methodology for assessing the investment attractiveness of industrial development is possible on the basis of a thorough selection of a large number of indicators by which investment attractiveness will be determined."

\section{AIMS}

The paper is aimed at evaluating the investment attractiveness of economic sectors based on an integrated indicator using Ukraine as an example.

\section{METHODS}

The general method of research is based on the use of an integrated approach to assessing investment attractiveness in terms of industries. The research method involves the use of relative indicators, as well as the use of weight coefficients. The following indicators were expertly identified: social significance of the sector, the coefficient of support for the sectoral development, the coefficient of sectoral production efficiency, return on investment, the index of competitiveness, the inflation index, and the investment attractiveness of the economy sector. Consider them in more detail.

a) Social significance of the sector (SSS). An indicator that reflects the importance of the sector for society. It may include the ratio of people employed in the sector to the total economically active population, the unemployment rate in the sector, etc., the sectoral level of GDP per capita.

$$
S S S=\frac{L_{i j}}{W F}
$$

where $L_{i j}$ - value of $i$-th parameter of employment in the $j$-th sector; $W F$ - the total number of economically active population.

b) Coefficient of support for the development of the sector (CSDS). This factor takes into account subsidies, transfers by sector, the share of capital investment, etc.

$$
\operatorname{CSDS}=\frac{I_{i j}}{I}
$$

where $I_{i j}$ - value of $i$-th parameter of capital investment in the $j$-th sector; $I$ - the total value of capital investment.

c) Production efficiency ratio (PER). It is advisable to calculate the indicator using the ratio of 
sales of goods and services within the sector to GDP.

$$
P E R=\frac{Q_{i j}}{G D P}
$$

where $Q_{i j}$ - value of $i$-th parameter of sales of goods and services in the $j$-th sector; GDP - sales of goods and services, volume of goods and services produced in the country during the year (Gross Domestic Product).

d) Capital productivity ratio $(C P R)$. The indicator reflects the efficiency of use of fixed assets and shows the volume of production per unit of fixed assets.

$$
C P R=\frac{Q_{i j}}{F_{i j}},
$$

where $F_{i j}$ - value of $i$-th parameter of value of fixed assets in the $j$-th sector.

e) Competitiveness index (CI). The factor may be based on an increase in the number of economic entities, or on an aggregate competition index and a dispersion of market shares.

$$
C I=\frac{C_{i j_{t}}-C_{i j_{(t-1)}}}{C_{i j_{(t-1)}}},
$$

where $C_{i j_{t}}$ - value of $i$-th parameter of entities in the $j$-th sector during the period of time $t$.

f) Inflation index. The indicator is not integrated. It allows taking into account the disincentive effect on investment attractiveness of the process of devaluation of money.

Given the different limits of change in the studied indicators - it is advisable to normalize them. For this purpose, were used the formula:

$$
x_{n_{i j}}=\frac{x_{i j}-x_{a v}}{\sqrt{n \cdot D}}
$$

where $x_{n_{i j}}$ - normalized value of $i$-th factor in the $j$-th sector; $x_{i j}$ - value of $i$-th factor in the $j$-th sector; $x_{a v}$ - avarage value of $\mathrm{i}$-th parameter; $D$ - the value of the variance of the group of indicators; $\mathrm{n}$ - number of periods in the research.
For each indicator, the coefficient of relative variance $\left(\delta_{i}\right)$ was calculated in the context of the period.

$$
\delta_{i}=\frac{x_{i j \max }-x_{i j \min }}{x_{i j \max }},
$$

where $x_{i j \max }-$ maximum value of $i$-th factor in the $j$-th sector; $x_{i j \min }-$ minimum value of $i$-th factor in the $j$-th sector.

Weights $\left(w_{i}\right)$ get the greatest value for those factors whose relative variance is the most significant. Weights are calculated by the formula:

$$
w_{i}=\frac{\delta_{i}}{\sum_{i=1}^{m} \delta_{i}},
$$

where $m$ - the number of factors in the research.

\section{RESULTS}

The effectiveness of investment measures depends on investment attractiveness of the particular sector of the economy. It should be noted that our previous work in the context of factor analysis formed the basis of modern research. Determining the investment attractiveness of a particular area of activity, it is necessary to consider a set of factors that make up the external conditions of the investment project. For example: the importance of the sector (the value of products, its features, the share of exports, dependence on imports, consumers of products; characteristics of consumption of the sector, the level of competition development, the peculiarities of the market, the actual and potential market volumes, the stability of the sector in relation to the general economic downturn in the country); the level of state intervention in the development of the sector (low, medium or high, including public capital investments, tax benefits, the possibility of accelerated depreciation); social significance of the sphere of activity (the number of jobs, regional location of production, average wages, trade union activities, environmental hazards of production and products, statistics of strikes and losses from them); financial conditions of the sector (the level of overall prof- 
itability, average profitability, return on invested capital, asset turnover, asset average liquidity).

Table 1 illustrates the indicators calculated on the basis of data from the State Statistics Service of Ukraine. All data for 2014-2019 are given without taking into account part of the temporarily occupied territories.

Table 1 shows that indicators have different limits of change. It is necessary to normalize indicators for further calculations. This will solve the problem of considering the limited number of indicators.

Table 1. Investment attractiveness indicators
The factors selected were listed for the research, but it must be taken into account the fact that not all factors have the same effect. It is possible to solve this problem with the use of weights.

The process of determining weights $\left(w_{i}\right)$ often causes difficulties. It is difficult to formalize weights' calculation and is usually performed by methods of expert evaluation. But such approach is quite resource-intensive and inevitably subjective. It is possible to formalize the process of obtaining weights if you use the numerical method, which is used to compare the characteristics of the set of variants of the researched system. The re-

Source: Authors' calculations.

\begin{tabular}{|c|c|c|c|c|c|c|c|c|c|c|}
\hline Indicators & $\frac{7}{0}$ & 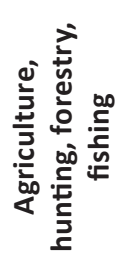 & 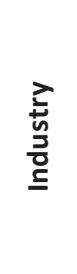 & 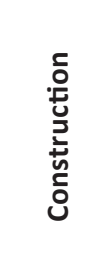 & 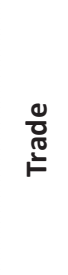 & 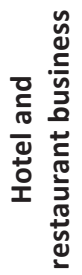 & 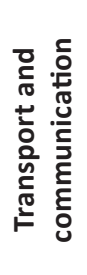 & 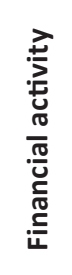 & 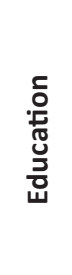 & 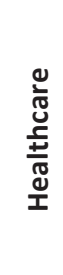 \\
\hline \multirow{10}{*}{$\begin{array}{l}\text { Social significance of } \\
\text { the sector }\end{array}$} & 2010 & 0.29 & 0.14 & 0.01 & 0.15 & 0.05 & 0.23 & 0.02 & 0.06 & 0.02 \\
\hline & 2011 & 0.30 & 0.14 & 0.01 & 0.15 & 0.04 & 0.25 & 0.02 & 0.06 & 0.02 \\
\hline & 2012 & 0.30 & 0.14 & 0.01 & 0.15 & 0.04 & 0.24 & 0.02 & 0.06 & 0.02 \\
\hline & 2013 & 0.30 & 0.15 & 0.01 & 0.15 & 0.04 & 0.23 & 0.02 & 0.06 & 0.01 \\
\hline & 2014 & 0.27 & 0.14 & 0.01 & 0.14 & 0.04 & 0.21 & 0.01 & 0.05 & 0.01 \\
\hline & 2015 & 0.25 & 0.13 & 0.01 & 0.15 & 0.03 & 0.20 & 0.01 & 0.05 & 0.01 \\
\hline & 2016 & 0.24 & 0.13 & 0.01 & 0.18 & 0.03 & 0.24 & 0.01 & 0.05 & 0.01 \\
\hline & 2017 & 0.23 & 0.13 & 0.12 & 0.20 & 0.03 & 0.31 & 0.01 & 0.05 & 0.01 \\
\hline & 2018 & 0.24 & 0.13 & 0.14 & 0.23 & 0.04 & 0.32 & 0.01 & 0.05 & 0.01 \\
\hline & 2019 & 0.22 & 0.13 & 0.15 & 0.26 & 0.03 & 0.35 & 0.01 & 0.05 & 0.02 \\
\hline \multirow{10}{*}{$\begin{array}{l}\text { Coefficient of support } \\
\text { for the sectoral } \\
\text { development }\end{array}$} & 2010 & 0.12 & 0.06 & 0.00037 & 0.31 & 0.16 & 0.21 & 0.01 & 0.05 & 0.03 \\
\hline & 2011 & 0.21 & 0.09 & 0.00023 & 0.44 & 0.18 & 0.27 & 0.01 & 0.06 & 0.03 \\
\hline & 2012 & 0.21 & 0.10 & 0.00021 & 0.51 & 0.23 & 0.27 & 0.01 & 0.06 & 0.04 \\
\hline & 2013 & 0.21 & 0.10 & 0.00016 & 0.54 & 0.23 & 0.25 & 0.01 & 0.08 & 0.04 \\
\hline & 2014 & 0.21 & 0.10 & 0.00015 & 0.48 & 0.20 & 0.23 & 0.01 & 0.09 & 0.03 \\
\hline & 2015 & 0.33 & 0.17 & 0.00031 & 0.49 & 0.24 & 0.28 & 0.01 & 0.10 & 0.04 \\
\hline & 2016 & 0.56 & 0.28 & 0.00026 & 0.65 & 0.25 & 0.35 & 0.01 & 0.14 & 0.04 \\
\hline & 2017 & 0.56 & 0.28 & 0.00034 & 0.68 & 0.25 & 0.33 & 0.01 & 0.14 & 0.04 \\
\hline & 2018 & 0.57 & 0.26 & 0.00036 & 0.64 & 0.31 & 0.34 & 0.01 & 0.14 & 0.05 \\
\hline & 2019 & 0.55 & 0.25 & 0.00038 & 0.69 & 0.32 & 0.42 & 0.01 & 0.14 & 0.06 \\
\hline \multirow{10}{*}{$\begin{array}{l}\text { Production efficiency } \\
\text { ratio }\end{array}$} & 2010 & 0.11 & 0.09 & 0.03 & 1.27 & 0.10 & 1.49 & 0.02 & 0.05 & 0.14 \\
\hline & 2011 & 0.10 & 0.08 & 0.02 & 1.14 & 0.09 & 1.12 & 0.01 & 0.06 & 0.13 \\
\hline & 2012 & 0.12 & 0.09 & 0.03 & 1.08 & 0.11 & 1.27 & 0.12 & 0.04 & 0.13 \\
\hline & 2013 & 0.11 & 0.09 & 0.03 & 1.02 & 0.10 & 1.28 & 0.06 & 0.04 & 0.11 \\
\hline & 2014 & 0.14 & 0.11 & 0.03 & 0.99 & 0.10 & 1.32 & 0.04 & 0.04 & 0.10 \\
\hline & 2015 & 0.25 & 0.14 & 0.04 & 0.96 & 0.08 & 1.34 & 0.12 & 0.05 & 0.10 \\
\hline & 2016 & 0.22 & 0.13 & 0.04 & 0.98 & 0.08 & 1.41 & 0.09 & 0.04 & 0.12 \\
\hline & 2017 & 0.21 & 0.14 & 0.04 & 0.97 & 0.08 & 1.42 & 0.09 & 0.04 & 0.13 \\
\hline & 2018 & 0.20 & 0.14 & 0.04 & 1.09 & 0.08 & 1.55 & 0.09 & 0.04 & 0.13 \\
\hline & 2019 & 0.21 & 0.14 & 0.04 & 1.00 & 0.09 & 1.63 & 0.10 & 0.05 & 0.13 \\
\hline
\end{tabular}


Table 1 (cont.). Investment attractiveness indicators

\begin{tabular}{|c|c|c|c|c|c|c|c|c|c|c|}
\hline Indicators & 흠 & 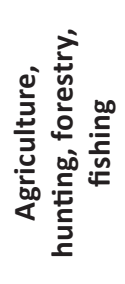 & 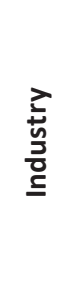 & 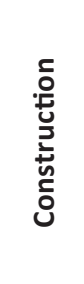 & $\begin{array}{l}\frac{0}{0} \\
\frac{\pi}{5} \\
\text { F }\end{array}$ & 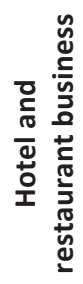 & 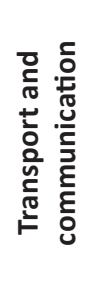 & 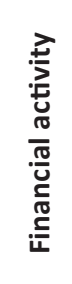 & 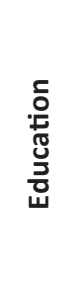 & 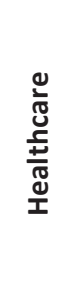 \\
\hline \multirow{10}{*}{$\begin{array}{l}\text { Capital productivity } \\
\text { ratio }\end{array}$} & 2010 & 1.04 & 0.81 & 26.00 & 1.25 & 1.68 & 15.10 & 0.54 & 0.06 & 2.86 \\
\hline & 2011 & 1.08 & 0.84 & 30.34 & 1.32 & 1.75 & 13.99 & 0.71 & 0.05 & 29.00 \\
\hline & 2012 & 1.21 & 0.94 & 37.73 & 0.95 & 2.11 & 12.91 & 5.72 & 0.01 & 4.71 \\
\hline & 2013 & 0.54 & 0.82 & 0.25 & 0.85 & 1.75 & 14.49 & 2.87 & 0.01 & 2.89 \\
\hline & 2014 & 0.65 & 0.99 & 0.30 & 0.81 & 2.40 & 14.31 & 2.21 & 0.01 & 3.21 \\
\hline & 2015 & 0.89 & 1.36 & 0.42 & 0.50 & 2.42 & 15.95 & 8.45 & 0.06 & 4.03 \\
\hline & 2016 & 0.77 & 1.18 & 0.36 & 0.76 & 2.49 & 14.98 & 7.20 & 0.07 & 3.86 \\
\hline & 2017 & 0.79 & 1.19 & 0.35 & 0.73 & 2.43 & 14.85 & 7.25 & 0.07 & 3.75 \\
\hline & 2018 & 0.77 & 1.19 & 0.37 & 0.63 & 2.46 & 14.22 & 7.06 & 0.06 & 3.80 \\
\hline & 2019 & 0.76 & 1.19 & 0.35 & 0.53 & 2.86 & 14.03 & 7.00 & 0.06 & 4.05 \\
\hline \multirow{10}{*}{ Competitiveness index } & 2010 & 1.24 & 1.03 & 1.21 & 1.25 & 1.01 & 1.02 & 1.03 & 1.04 & 1.05 \\
\hline & 2011 & 1.46 & 1.04 & 1.29 & 1.71 & 1.02 & 1.03 & 1.03 & 1.05 & 1.06 \\
\hline & 2012 & 0.74 & 1.04 & 0.83 & 0.63 & 1.03 & 1.02 & 1.02 & 1.01 & 1.11 \\
\hline & 2013 & 1.02 & 1.05 & 1.05 & 1.01 & 1.01 & 1.01 & 1.05 & 1.01 & 1.04 \\
\hline & 2014 & 1.01 & 1.01 & 0.76 & 1.01 & 1.05 & 1.05 & 1.07 & 1.02 & 1.01 \\
\hline & 2015 & 1.02 & 1.05 & 1.75 & 1.01 & 1.03 & 1.02 & 1.02 & 1.01 & 1.03 \\
\hline & 2016 & 0.98 & 0.94 & 0.75 & 1.00 & 1.01 & 1.02 & 1.01 & 1.03 & 1.04 \\
\hline & 2017 & 1.18 & 1.05 & 0.96 & 1.00 & 1.01 & 1.02 & 1.01 & 1.03 & 1.04 \\
\hline & 2018 & 1.11 & 1.05 & 0.85 & 1.00 & 1.01 & 1.02 & 1.02 & 1.03 & 1.04 \\
\hline & 2019 & 1.26 & 1.03 & 0.90 & 1.00 & 1.01 & 1.02 & 1.03 & 1.04 & 1.05 \\
\hline \multirow{10}{*}{ Inflation index } & 2010 & 1.1825 & 1.18 & 1.11 & 1.05 & 1.09 & 1.09 & 1.07 & 1.10 & 1.04 \\
\hline & 2011 & 1.1120 & 1.11 & 1.06 & 1.04 & 1.17 & 1.07 & 1.08 & 1.18 & 1.02 \\
\hline & 2012 & 1.0270 & 1.03 & 0.98 & 1.01 & 1.03 & 1.04 & 1.05 & 1.08 & 0.99 \\
\hline & 2013 & 1.0310 & 1.03 & 0.98 & 1.00 & 1.00 & 1.02 & 1.02 & 1.02 & 0.97 \\
\hline & 2014 & 1.1445 & 1.14 & 1.12 & 1.08 & 1.16 & 1.11 & 1.07 & 1.25 & 1.02 \\
\hline & 2015 & 1.3955 & 1.40 & 1.46 & 1.39 & 2.16 & 1.39 & 1.24 & 1.37 & 1.33 \\
\hline & 2016 & 1.1080 & 1.11 & 1.09 & 1.12 & 1.35 & 1.10 & 1.13 & 1.07 & 1.16 \\
\hline & 2017 & 1.1222 & 1.22 & 1.27 & 1.26 & 1.26 & 1.17 & 1.32 & 1.11 & 1.18 \\
\hline & 2018 & 1.1256 & 1.21 & 1.36 & 1.30 & 1.31 & 1.22 & 1.33 & 1.21 & 1.20 \\
\hline & 2019 & 1.235 & 1.38 & 1.40 & 1.31 & 1.40 & 1.30 & 1.31 & 1.26 & 1.21 \\
\hline
\end{tabular}

sulting matrix reflects the properties of the system in the whole range of variation of parameters and serves. On the one hand, the matrix can be used as a basis for finding optimal values, and on the other - a basis for formalized calculation of weights that take into account the relative importance of each factor. There were calculated the coefficient of relative scatter $\left(\delta_{i}\right)$ in terms of the researched period (7) and weights $\left(w_{i}\right)$ for each indicator (8). The weights $\left(w_{i}\right)$ are the most important for those factors whose relative variance is the most significant.

The next step is to build a matrix of weights:

$$
W=\begin{array}{llllllllll}
x_{1} & .09 & .07 & .24 & .08 & .13 & .12 & .04 & .06 & .13 \\
x_{2} & .28 & .36 & .16 & .23 & .24 & .31 & .15 & .20 & .20 \\
x_{3} & .17 & .21 & .11 & .06 & .14 & .21 & .35 & .30 & .13 \\
x_{4} & .20 & .19 & .26 & .26 & .21 & .15 & .37 & .33 & .38 \\
x_{5} & .17 & .05 & .14 & .26 & .02 & .01 & .02 & .01 & .04 \\
x_{6} & .09 & .12 & .09 & .12 & .27 & .20 & .07 & .10 & .11
\end{array}
$$


Table 2. Determining the most influential group of factors

Source: Authors' calculations

\begin{tabular}{|c|c|c|c|c|c|c|c|c|c|c|c|}
\hline Indicators & 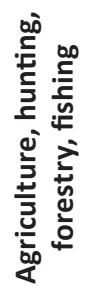 & 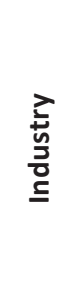 & 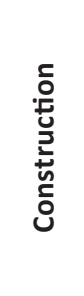 & $\begin{array}{l}\frac{0}{6} \\
\frac{\pi}{10}\end{array}$ & 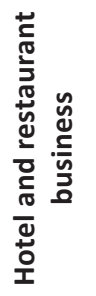 & 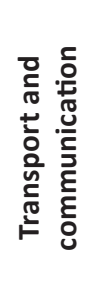 & 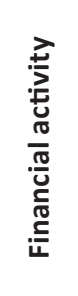 & 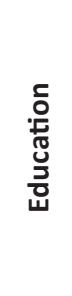 & 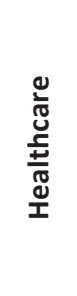 & 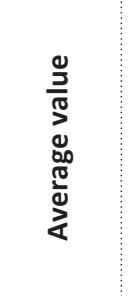 & 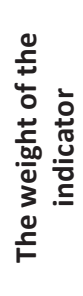 \\
\hline $\begin{array}{l}\text { Capital } \\
\text { productivity ratio }\end{array}$ & 0.20 & 0.19 & 0.26 & 0.26 & 0.21 & 0.15 & 0.37 & 0.33 & 0.38 & 0.26 & 1 \\
\hline $\begin{array}{l}\text { Coefficient of } \\
\text { support for } \\
\text { the sectoral } \\
\text { development }\end{array}$ & 0.28 & 0.36 & 0.16 & 0.23 & 0.24 & 0.31 & 0.15 & 0.20 & 0.20 & 0.24 & 2 \\
\hline $\begin{array}{l}\text { Production } \\
\text { efficiency ratio }\end{array}$ & 0.17 & 0.21 & 0.11 & 0.06 & 0.14 & 0.21 & 0.35 & 0.30 & 0.13 & 0.19 & 3 \\
\hline Inflation index & 0.09 & 0.12 & 0.09 & 0.12 & 0.27 & 0.20 & 0.07 & 0.10 & 0.11 & 0.13 & 4 \\
\hline $\begin{array}{l}\text { Social } \\
\text { significance of } \\
\text { the sector }\end{array}$ & 0.09 & 0.07 & 0.24 & 0.08 & 0.13 & 0.12 & 0.04 & 0.06 & 0.13 & 0.11 & 5 \\
\hline $\begin{array}{l}\text { Competitiveness } \\
\text { index }\end{array}$ & 0.17 & 0.05 & 0.14 & 0.26 & 0.02 & 0.01 & 0.02 & 0.01 & 0.04 & 0.08 & 6 \\
\hline $\begin{array}{l}\stackrel{n}{0} \\
\stackrel{0}{0} \\
. \frac{0}{0} \\
\underline{\Xi}\end{array}$ & 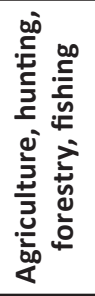 & 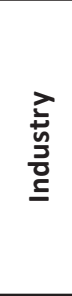 & 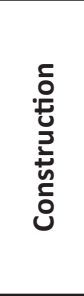 & 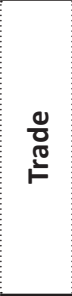 & 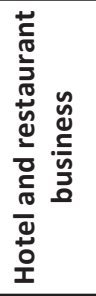 & 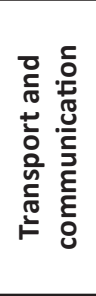 & 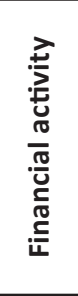 & 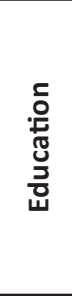 & 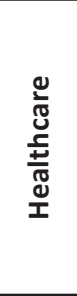 & 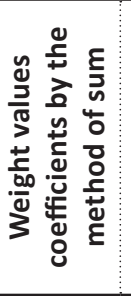 & 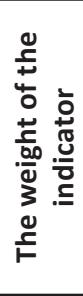 \\
\hline $\begin{array}{l}\text { Capital } \\
\text { productivity ratio }\end{array}$ & 2 & 3 & 1 & 1 & 3 & 5 & 1 & 1 & 1 & 18 & 1 \\
\hline $\begin{array}{l}\text { Coefficient of } \\
\text { support for } \\
\text { the sectoral } \\
\text { development }\end{array}$ & 1 & 1 & 3 & 2 & 2 & 1 & 3 & 3 & 2 & 18 & 2 \\
\hline $\begin{array}{l}\text { Production } \\
\text { efficiency ratio }\end{array}$ & 3 & 2 & 5 & 5 & 4 & 2 & 2 & 2 & 3 & 28 & 3 \\
\hline Inflation index & 4 & 4 & 6 & 3 & 1 & 3 & 4 & 4 & 4 & 33 & 4 \\
\hline $\begin{array}{l}\text { Social } \\
\text { significance of } \\
\text { the sector }\end{array}$ & 4 & 5 & 2 & 4 & 5 & 4 & 5 & 5 & 3 & 37 & 5 \\
\hline $\begin{array}{l}\text { Competitiveness } \\
\text { index }\end{array}$ & 3 & 6 & 4 & 1 & 6 & 6 & 6 & 6 & 5 & 43 & 6 \\
\hline
\end{tabular}

It becomes possible to determine the most influential group of factors in terms of evaluation using the method of weights. For this, the average value of the weighting factor within a particular sector was calculated using the sum of sets method. This method involves ranking the indicators by the place of the indicator by the value of the weights.

The factors of capital efficiency and state support of the sector have the most significant impact on the sectoral investment attractiveness. Such re- sults are quite logical. The Production efficiency ratio reflects the real level of efficiency in the use of existing fixed assets. The government support provides favorable conditions for business operation. At the same time, the impact of competition on the investment attractiveness of the sector is insignificant.

Based on the above indicators, an approach to the integrated assessment of investment attractiveness of the economy sector was proposed. To build an integrated indicator of investment attractiveness, 
Table 3. Calculation of the integrated indicator of investment attractiveness of the economy sector

Source: Authors' calculations

\begin{tabular}{|c|c|c|c|c|c|c|c|c|c|}
\hline Period & 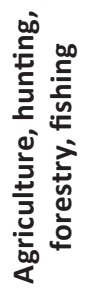 & 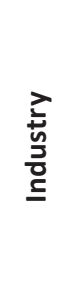 & 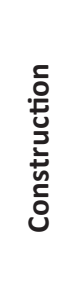 & 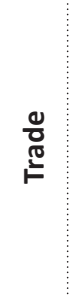 & 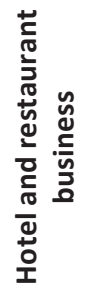 & 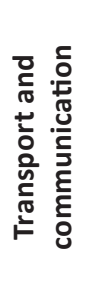 & 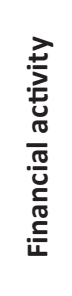 & 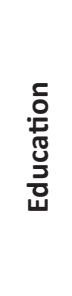 & 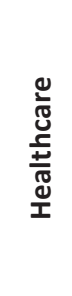 \\
\hline 2010 & 0.12 & 0.27 & 0.09 & 0.16 & 0.15 & 0.15 & 0.38 & 0.02 & 0.02 \\
\hline 2011 & 0.05 & 0.21 & 0.04 & 0.26 & 0.17 & 0.14 & 0.30 & 0.01 & 0.03 \\
\hline 2012 & 0.11 & 0.22 & 0.04 & 0.25 & 0.14 & 0.12 & 0.30 & 0.04 & 0.04 \\
\hline 2013 & 0.15 & 0.25 & 0.17 & 0.24 & 0.14 & 0.10 & 0.25 & 0.06 & 0.05 \\
\hline 2014 & 0.16 & 0.21 & 0.21 & 0.25 & 0.19 & 0.18 & 0.18 & 0.06 & 0.14 \\
\hline 2015 & 0.11 & 0.22 & 0.21 & 0.24 & 0.28 & 0.16 & 0.16 & 0.01 & 0.23 \\
\hline 2016 & 0.11 & 0.24 & 0.22 & 0.26 & 0.26 & 0.19 & 0.19 & 0.05 & 0.21 \\
\hline 2017 & 0.12 & 0.27 & 0.22 & 0.27 & 0.25 & 0.25 & 0.25 & 0.08 & 0.25 \\
\hline 2018 & 0.14 & 0.27 & 0.21 & 0.25 & 0.26 & 0.28 & 0.21 & 0.15 & 0.26 \\
\hline 2019 & 0.14 & 0.26 & 0.23 & 0.26 & 0.25 & 0.34 & 0.18 & 0.15 & 0.27 \\
\hline $\begin{array}{l}\text { Average sectoral } \\
\text { value }\end{array}$ & 0.12 & 0.24 & 0.16 & 0.24 & 0.21 & 0.19 & 0.24 & 0.06 & 0.15 \\
\hline
\end{tabular}

the method of weights was used. The proposed attractiveness index varies from 0 to 1 . The sum of the weights should equal one. The indicators considered above are stimulants. Given the weighted estimates (8), the following is proposed:

$$
I A I=\left(\sum_{i=1}^{m}\left|x_{m_{i j}}\right| \cdot w_{i}\right), \text { at } 0 \leq x_{m_{i j}} \leq 1,
$$

where $I A I$ - (investment attractiveness indicator) is an integrated indicator of investment attractiveness of the economy sector, its lower limit of change is determined by the fact that the calculation is selected normalized indicators whose values are less than one $(0 \leq I A I \leq 1)$.

Using formula (10), the investment attractiveness in terms of industries was calculated (Table 3).

If the value of the index (10) grows, the level of investment attractiveness grows too. It will be useful to complement the existing tools with the proposed approach. This allows one to more completely and thoroughly study the processes of attracting investment in individual sectors of the economy.

Table 3 shows that in terms of the period under study, the most attractive are industry, trade, transport and communications, as well as financial activities. The sphere of education remains the least attractive for investment. The problem of radical reform of this sector is especially acute in modern realities. Most reforms of education remain superficial. In the vast majority of cases the measures taken by educational institutions are aimed at achieving quantitative rather than qualitative indicators. Stimulating investment in education is possible only if it will give financially effect. In the near future, Ukraine will not be able to avoid the reduction of educational institutions. It is necessary to provide the establishment of strict requirements for the quality of education. Also, education needs reform in the field of the introduction of a national system for assessing the level of knowledge of graduates and coordination with employers. Comparing the obtained values with the actual situation of distribution of capital investments in terms of industries (Figure 1), it can be seen that this ratio is maintained.

From Table 3 it becomes clear that over the past 10 years there has been a tendency to increase investment attractiveness. The exception is financial activity, which is quite sensitive to any economic fluctuations both within the country and abroad. At the same time, the average level of attractiveness remains sufficient. In Ukraine, industry and trade have traditionally been profitable for investment. Industrial giants feel quite confident in a destabilizing economy. Another important area is trade. 
Source: Site of the State Statistics Service of Ukraine. Retrieved from http://www.ukrstat.gov.ua

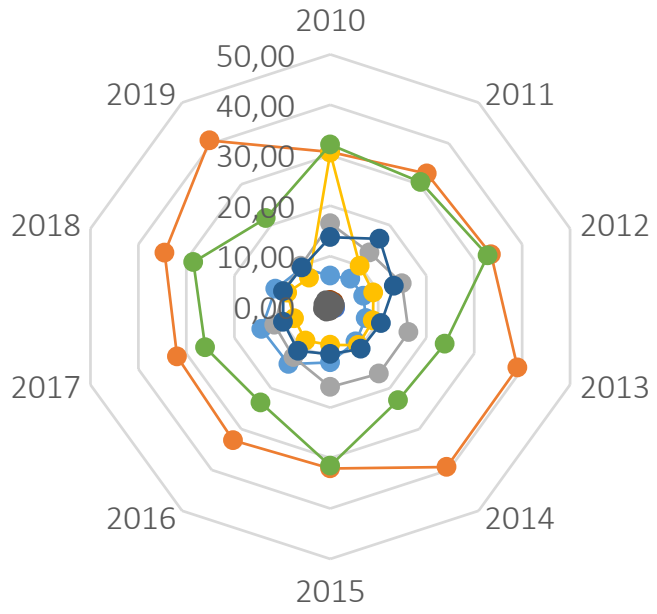

Figure 1. Dynamics of sectoral capital investments

The COVID-19 pandemic shook the world in 2020 and forced companies to switch a significant part of their trading operations online. This pandemic has significantly damaged the investment attractiveness of the trade sector. Transport and communications are becoming more attractive for investment as a result of recent road construction. In addition, the general trend towards informatization of society and the transition to modern technologies contributes to the development of the sector.

Particularly positive changes can be observed in the field of health care. According to Table 3, the attractiveness of this health care has increased essentially increased by a factor of 10 to the initial researched period. Obviously, the key reason for such growth is the effective reform of the sector, increasing the number of private clinics and laboratories, the introduction of a donor transplant system. The COVID-19 pandemic provided a significant impetus for the development of the sector. In conditions of a high level of disease outbreak due to coronavirus, were observed a general activation of the sector. All this gave impetus to the development of domestic medicine, the need for new research and additional external funding.

Investment management also includes economic and regulatory methods, which can be used to provide the necessary direction of investment activities and obtain the desired results. State regulation of investment activities needs to implement economic, scientific, technical and social policy. It is determined by plans and programs for economic development, budgets and the amount of public funding provided for this purposes. This creates favorable conditions for investors who carry out investment activities in the most important areas to meet social needs, and especially in the direction of technical improvement of production and implementation of discoveries and inventions.

Thus, in the macroeconomic aspect, investment activity is a process of laying the future of the country's economy. The growth of investment today is the basis for high growth rates of GDP tomorrow. The investment climate is formed under the influence of various political, institutional, legal, economic and social factors. The same factors determine how attractive the particular sector is to a potential investor. Thus, the creation of a favorable investment climate is associated with "good governance" of investment attractiveness.

\section{DISCUSSION}

The problem of taking into account the maximum possible range of factors is especially relevant for such studies. The significance of the factor is determined by the degree of its impact on the object of study. A logical question arises as to what factors to use in the study. To this end, it is advisable to use methods of correlation-regression analysis to avoid multicollinearity and to determine statistically significant indicators. 
Obviously, the proposed approach does not take into account some factors. These calculations were abstracted from a number of factors, such as legal restrictions, the impact of globalization, sector-specific risks. Risk assessment is a particularly important stage of investment activity. Qualitative risk analysis involves identifying causal relationships, identifying potential risk areas; forecasting the possible negative consequences of the manifestation of risks. The results of qualitative risk analysis are the basic basis for quantitative analysis. Quantitative analysis is formalized using the methods of mathematical statistics. At the stage of quantitative risk analysis, it is advisable to calculate the numerical values of individual risks. It is also important to predict possible losses. An important step is also the calculation of the cost equivalent of anti-crisis measures. Key risks are specific to each sector. For example, for education it can be a low rating of educational institutions or reduction of students / entrants. And for agriculture, it is seasonality, dependence on weather conditions, etc.
Legal factors, the impact of globalization, the impact of the world market can be assessed on the basis of a system of points from 0 to 1 (where 0 - the impact is insignificant, i.e. such that can be neglected; 0.5 - there is a certain level of barriers that complicate but do not make it impossible for enterprises and organizations; 1restrictions are high, market access for potential participants is very limited or almost closed). Similarly, in our opinion, it is possible to assess the regulatory and legal environment: 1 - legal environment favorable for business development; 0.5 - existing liberal state regulation and minor restrictions; 0 - strict state control and significant legal restrictions, the need for a significant number of permits and licensing.

Future study of these factors gives one the opportunity to take them into account when calculating the integrated indicator of investment attractiveness of the economy sector. It also involves the use of methods of economic and mathematical modeling, therefore it will be the subject of further research.

\section{CONCLUSION}

This study presents the prospects for assessing the investment attractiveness of the economy sectors based on an integrated indicator using Ukraine as an example.

For this purpose, the factors were identified such as: the social significance of the sector, the coefficient of support for the sectoral development, the coefficient of production efficiency, the index of fierce competition, and the inflation index. The results of the factor analysis confirm that the factors of economic efficiency and state support of the sector have the most significant impact on the investment attractiveness. At the same time, the impact of competition on the investment attractiveness was insignificant.

The calculation of the developed investment attractiveness indicator showed that the most attractive sectors are: industry, trade, transport and communications and financial activities. At the same time, it has been found that the education sector remains the least attractive for investment. Transport and communications have become more attractive for investment as a result of recent road construction. The study found that there have been positive developments in health care. Improving the efficiency of the industry becomes possible only if a favorable investment environment is created. It is possible to increase the effectiveness of measures and minimize the risks of investors by applying a comprehensive approach in the investment policy of the state.

These results are insightful, however some limitations are acknowledged, so it provides opportunities for further research. The existing tools for assessing the investment attractiveness of the economy sector can be supplement by the proposed approach. This will provide a more complete and thorough study of the processes of attracting investment in certain sectors of the economy. The conducted empirical analysis can become a basis for further research in order to make informed decisions to improve the investment climate in Ukraine, increase the volume of foreign and capital investment. 


\section{AUTHOR CONTRIBUTIONS}

Conceptualization: Iurii Umantsiv.

Data curation: Iurii Umantsiv.

Formal analysis: Yuliia Sonko.

Investigation: Iurii Umantsiv, Ivan Cherlenjak, Volodymyr Prikhodko, Yuliia Sonko, Maryna Shtan.

Resourses: Iurii Umantsiv, Ivan Cherlenjak, Volodymyr Prikhodko, Yuliia Sonko, Maryna Shtan.

Methodology: Iurii Umantsiv, Ivan Cherlenjak, Yuliia Sonko.

Supervision: Iurii Umantsiv, Ivan Cherlenjak, Volodymyr Prikhodko.

Validation: Iurii Umantsiv, Ivan Cherlenjak, Volodymyr Prikhodko.

Visualization: Maryna Shtan.

Writing - original draft: Iurii Umantsiv, Ivan Cherlenjak, Volodymyr Prikhodko, Yuliia Sonko, Maryna Shtan.

Writing - reviewing and editing: Yuliia Sonko.

\section{ACKNOWLEDGEMENTS}

This article was prepared and funded within the research theme "Strategy of structural reorientation of Ukraine's economy in the conditions of a pandemic" reg. No. 0121 U109608 of Economic Theory and Competitive Policy Department of Kyiv National University of Trade and Economics.

\section{REFERENCES}

1. Blank, I. A. (2001). IInvestitsionnyy menedzhment [Investment management]. (In Russian). Kyiv: Elha-N, Nika-Centre, Ukraine. Retrieved from http://www.dut. edu.ua/uploads/1_1592_62002987. pdf

2. Borowicz, A., Kostyra, M., Dzierżanowski, M., Szultka, S. (Ed.)., \& Wandałowski, M. (2016). The Investment Attractiveness of voivodships and the sub-regions in Poland 2016. Gdańsk: The Gdańsk Institute for Market Economics.

3. Dovhan, Y. (2015). Assessment of the investment attractiveness. Finance, accounting, banks, 1(21), 235-244. Retrieved from http:// socrates.vsau.edu.ua/repository/ getfile.php/16950.pdf

4. Gliznutsa, M. Y. (2016). Vyznachennnia skladovykh ta otsinka innovatsiinoho potentsialu rehionu [Determination of the components and assessment of the region's innovation potential]. Tekhnologicheskiy audit i reservy proizvodstva - Technology audit and production reserves, 3/5(29), 11-14. (In Ukrainian). Retrieved from http://www.irbis-nbuv.gov. ua/cgi-bin/irbis_nbuv/cgiirbis_64. exe?I21DBN=LINK\&P21DBN= UJRN\&Z21ID $=\& S 21 R E F=10 \& S$ $21 \mathrm{CNR}=20 \& S 21 \mathrm{STN}=1 \& S 21 \mathrm{FM}$ $\mathrm{T}=\mathrm{ASP} \_$meta\&C21COM=S\&2_ S21P03=FILA $=\& 2$ S21STR=Tatrv_2016_3(5)_3

5. Globerman, S., \& Shapiro, D. (1999). The Impact of Government Policies on Foreign Direct Investment: The Canadian Experience. Journal of International Business Studies, 30(3), 513-532. Retrieved from https://link. springer.com/article/10.1057/palgrave.jibs. 8490081

6. Gutkevych, S. (2019). Investment attractiveness of industries: features and trends. Baltic Journal of Economic Studies, 5(3), 50-58. https://doi.org/10.30525/22560742/2019-5-3-50-58

7. Gutkevych, S. O., \& Pulii, O. V. (2019). Investytsiina pryvablyvist: sutnist, pokaznyky i chynnyky vplyvu [Investment attractiveness: essence, indicators and factors of influence]. Intelekt XXI, 2, 88-93. Retrieved from http://dspace.nuft.edu.ua/jspui/ handle/123456789/29900
8. Hajduts'kyj, A. P. (2004). Otsinka investytsiinoi pryvablyvosti ekonomiky [Evaluation of investment attractiveness of the economy]. Ekonomika i prohnozuvannia - Economy and forecasting, 3, 119-128. (In Ukrainian). Retrieved from http://eip.org.ua/docs/ EP_04_4_119_uk.pdf

9. Hryhoruk, P. M., \& Khrushch, N A. (2016). Intehralne otsiniuvannia rivnia ta dynamiky innovatsiinoho potentsialu rehionu [Complex assessment of the level and dynamics of innovative capacity of region]. Visnyk Khmelnytskoho natsionalnoho universytetu. Ekonomichni nauky - Herald of Khmelnytskyi National University. Economic Sciences, 3(3), 109-129. (In Ukrainian). Retrieved from https://mmi.fem. sumdu.edu.ua/sites/default/files/ mmi2016_3_109_129_0.pdf

10. Irtyshcheva, I. O., Stehnei, M. I., \& Pauk, M. I. (2014). Metodychni pidkhody do vyznachennia rivnia investytsiinoi pryvablyvosti haluzi, pidpryiemstva [Methodical approaches to determining the level of investment attractiveness of the industry, enterprise]. Visnyk 
KhNAU. Seriia: Ekonomichni nauky - KhNAU Bulletin, 5, 15-24. (In Ukrainian). Retrieved from http://www.irbis-nbuv.gov.ua/ cgi-bin/irbis_nbuv/cgiirbis_64.ex e? I21DBN=LINK\&P21DBN=U $J R N \& Z 21 I D=\& S 21 R E F=10 \& S 2$ $1 \mathrm{CNR}=20 \& S 21 \mathrm{STN}=1 \& \mathrm{~S} 21 \mathrm{FM}$ $\mathrm{T}=\mathrm{ASP} \_$meta\&C $21 \mathrm{COM}=\mathrm{S} \& 2$ S21P03 $=$ FILA $=\& 2$ S21STR=Vkhnau_ekon_2014_5_5

11. Jantoń-Drozdowska, E., \& Majewska, M. (2016). Investment attractiveness of central and Eastern European countries in the light of new locational advantages development. Equilibrium. Quarterly Journal of Economics and Economic Policy, 11, 97-119. https://doi. org/10.12775/EQUIL.2016.005

12. Kharlamova, G (2014). Investment attractiveness of Ukrainian regions: rating assessment and marketing promotion. Journal of International Studies, 7(1), 9-26. https://doi.org/10.14254/2071$8330.2014 / 7-1 / 1$

13. Krykhivs'ka, N. O., \& Chernyshova, H. M. (2017). Investytsiyna pryvablyvist' Ukrayiny: osnovni problemy ta shlyakhy yikh vyrishennya Investytsiina pryvablyvist Ukrainy: osnovni problemy ta shliakhy yikh vyrishennia. Ekonomika i suspilstvo - Economics and Society, 9, 260-264. (In Ukrainian). Retrieved from https:// economyandsociety.in.ua/journals/9_ukr/45.pdf

14. Maliuta, K. (2019). Factors of Investment Attractiveness of the Tourist Sector of Ukraine. Modern Economics, 13, 168-173. https:// doi.org/10.31521/modecon. V13(2019)-26

15. Mustakerov, I., \& Borissova, D. (2013). Investments Attractiveness via Combinatorial Optimization Ranking, World Academy of Science. Engineering and Technology International Journal of Econom$i c s$ and Management Engineering, 7(10), 2674-2679. Retrieved from https://publications.waset. org/17005/investments-attractiveness-via-combinatorial-optimization-ranking

16. Naumenko, I. V., Naumenko, A. O., \& Mandych, O. V. (2015). Intehralna otsinka zabezpechennia efektyvnosti vykorystannia resursnoho potentsialu ahrarnykh pidpryiemstv [Integrated assessment to ensure efficient use of the resource potential of agricultural enterprises]. Visnyk KHNAU im.V.V. Dokuchayeva. Ekonomichni nauky, 5, 2256-260. (In Ukrainian). Retrieved from http://nbuv.gov.ua/UJRN/Vkhnau_ekon_2015_5_30

17. Nosova, O. V. (2003). Evaluation of investment attractiveness of Ukraine: the main approaches. Ekonomika i prohnozuvannia, 3, 119-137. (In Ukrainian). Retrieved from http://eip.org.ua/?page $\mathrm{id}=523 \&$ aid $=180$

18. Ovcharenko, T. S., \& Stepanova, A. A. (2017). Metodychni pidkhody shchodo vyznachennia investytsiinoi pryvablyvosti haluzei Ukrainy [Methodical approaches to determining the investment attractiveness of Ukrainian industries]. Molodyi vchenyi, 5, 684-689. Retrieved from http://nbuv.gov.ua/ UJRN/molv_2017_5_154

19. Ramachandran, R., Sasidharan, S., \& Doytch, N. (2020). Foreign direct investment and industrial agglomeration. Evidence from India, Economic Systems, 44(4). https://doi.org/10.1016/j.ecosys.2020.100777

20. Reverchuk, S., Vovchak, O., Yavorska, T., Voytovych, L., \& Irshak, O. (2020). Investment activities of banks, insurance companies, and non-government pension funds in Ukraine. Investment Management and Financial Innovations, 17(2), 353-363. https://doi.org/10.21511/ imfi.17(2).2020.27

21. Riabovolyk, T. F. (2017). Osnovni skladovi intehralnoi otsinky innovatsiinoho potentsialu rehioniv v umovakh klasteryzatsii natsionalnoi ekonomiky [The main components of an integrated assessment of the innovation potential of regions in the conditions of clustering of the national economy]. Ekonomika: realii chasu. Naukovyi zhurnal, 4(32), 69-77. (In Ukrainian). Retrieved from http://dspace.kntu.kr.ua/jspui/ handle/123456789/7162

22. Site of the State Statistics Service of Ukraine. (n.d.). Retrieved from http://www.ukrstat.gov.ua
23. Sonko, Yu., Lazebna, I., \& Lebedeva, L. (2018). Material production and GDP in Ukraine: theoretical concept and financial assessment. Investment management and financial innovations, 15(2), 51-59. https://doi.org/10.21511/ imfi.15(2).2018.05

24. Sydor G. V., \& Davydovska G. I. (2015). Investytsiina pryvablyvist rehioniv [Investment attractiveness of regions]. Stalyi rozvytok ekonomiky, 2, 185-186. (In Ukrainian). Retrieved from http://nbuv. gov.ua/UJRN/sre_2015_2_28

25. Yehorov, I. Yu. (2012). Problemy pobudovy uzahalniuiuchykh indeksiv na osnovi balnykh otsinok u suchasnii ekonomitsi (na prykladi deiakykh indeksiv dlia Ukrainy) [Problems of construction of generalizing indices on the basis of point estimations in modern economy (on an example of some indices for Ukraine)]. Formuvannia rynkovykh vidnosyn, 5(132), 90-94. (In Ukrainian). Retrieved from http://nbuv.gov.ua/ UJRN/frvu_2012_5_22

26. Yemelianov, O. Yu., Kret, I. Z., \& Sehedii, O. M. (2003). Informatsiine zabezpechennia analizu investytsiinoho potentsialu haluzei ekonomiky [Information support of the analysis of investment potential of branches of economy]. Visnyk Natsionalnoho universytetu "Lvivska politekhnika" Problemy ekonomiky ta upravlinnia, 484, 6671. (In Ukrainian). Retrieved from http://ena.lp.edu.ua:8080/handle/ $\mathrm{ntb} / 9049$ 